\section{Web of Science}

\section{Clarivate Analytics}

\section{Search Search Results}

Tools - Searches and alerts - Search History Marked List

ఠ Free Accepted Article From Repository

Find PDF

Full Text Options

Export.

Add to Marked List

\section{Scaffolds for Cartilage Regeneration: To Use or Not to Use?}

By: Sha'ban, M (Sha'ban, Munirah) ${ }^{[1]}$; Radzi, MAA (Radzi, Muhammad Aa'zamuddin Ahmad) ${ }^{[2]}$

BIOINSPIRED BIOMATERIALS: ADVANCES IN TISSUE ENGINEERING AND REGENERATIVE MEDICINE

Edited by: Chun, HJ; Reis, RL; Motta, A; Khang, G

Book Series: Advances in Experimental Medicine and Biology

Volume: 1249 Pages: 97-114

DOI: $10.1007 / 978-981-15-3258-0 \_7$

Published: 2020

Document Type: Article; Book Chapter

View Journal Impact

\section{Abstract}

Joint cartilage has been a significant focus on the field of tissue engineering and regenerative medicine (TERM) since its inception in the 1980s. Represented by only one cell type, cartilage has been a simple tissue that is thought to be straightforward to deal with. After three decades, engineering cartilage has proven to be anything but easy. With the demographic shift in the distribution of world population towards ageing, it is expected that there is a growing need for more effective options for joint restoration and repair. Despite the increasing understanding of the factors governing cartilage development, there is still a lot to do to bridge the gap from bench to bedside. Dedicated methods to regenerate reliable articular cartilage that would be equivalent to the original tissue are still lacking. The use of cells, scaffolds and signalling factors has always been central to the TERM. However, without denying the importance of cells and signalling factors, the question posed in this chapter is whether the answer would come from the methods to use or not to use scaffold for cartilage TERM. This paper presents some efforts in TERM area and proposes a solution that will transpire from the ongoing attempts to understand certain aspects of cartilage development, degeneration and regeneration. While an ideal formulation for cartilage regeneration has yet to be resolved, it is felt that scaffold is still needed for cartilage TERM for years to come.

\section{Keywords}

Author Keywords: Biomaterial; Cartilage; Chondrocytes; Development; Regeneration; Regenerative medicine; Scaffolds; Tissue engineering

KeyWords Plus: CONSTRUCTS; HYDROGEL; BONE

\section{Author Information}

\section{Reprint Address:}

International Islamic University Malaysia Int Islamic Univ Malaysia, Kulliyyah Allied HIth Sci, Dept Phys Rehabil Sci, Kuantan, Pahang, Malaysia.

Corresponding Address: Sha'ban, M (corresponding author)

+ Int Islamic Univ Malaysia, Kulliyyah Allied HIth Sci, Dept Phys Rehabil Sci, Kuantan, Pahang, Malaysia. Addresses:

+ [1] Int Islamic Univ Malaysia, Kulliyyah Allied Hlth Sci, Dept Phys Rehabil Sci, Kuantan, Pahang, Malaysia

+ [2 ] Int Islamic Univ Malaysia, Kulliyyah Allied HIth Sci, Dept Biomed Sci, Kuantan, Pahang, Malaysia

E-mail Addresses: munirahshaban@iium.edu.my

Funding

\begin{tabular}{|c|c|c|}
\hline Funding Agency & Show details & Grant Number \\
\hline Ministry of Education (MOE) Malaysia & & TRGS/1/2016/UIAM/02/8/2 (TRGS16-02- \\
\hline
\end{tabular}

\section{Citation Network}

In Web of Science Core Collection

0

Times Cited

Create Citation Alert

\section{2}

Cited References

View Related Records

\section{Use in Web of Science}

Web of Science Usage Count

3

Last 180 Days Since 2013

Learn more

\section{This record is from:}

Web of Science Core Collection

- Science Citation Index Expanded

- Book Citation Index- Science

Suggest a correction

If you would like to improve the quality of the data in this record, please suggest a correction. 


\begin{tabular}{|l|l|} 
& 002-0002) TRGS/1/2016/UIAM/02/8 \\
\hline $\begin{array}{l}\text { Ministry of Energy, Science, Technology, Environment and } \\
\text { Climate Change (MESTECC), Malaysia }\end{array}$ & SF14-012-0062/06-01-08-SF0238 \\
\hline $\begin{array}{l}\text { Kulliyyah of Allied Health Sciences, International Islamic } \\
\text { University Malaysia (IIUM), Kuantan Campus, Pahang, Malaysia }\end{array}$ & \\
\hline $\begin{array}{l}\text { Tissue Engineering and Regenerative Medicine Research Team, } \\
\text { IIUM }\end{array}$ & \\
\hline
\end{tabular}

View funding text

\section{Publisher}

SPRINGER-VERLAG SINGAPORE PTE LTD, 152 BEACH ROAD, \#21-01/04 GATEWAY EAST, SINGAPORE, 189721, SINGAPORE

\section{Journal Information}

Impact Factor: Journal Citation Reports

\section{Categories / Classification}

Research Areas: Cell Biology; Materials Science

Web of Science Categories: Cell \& Tissue Engineering; Materials Science, Biomaterials

\section{See more data fields}

\section{Cited References: 62}

1. Scaffold-free bioprinting of mesenchymal stem cells using the Regenova printer: Spheroid characterization and

Times Cited: 12 osteogenic differentiation

By: Aguilar, Izath Nizeet; Olivos, David J., III; Brinker, Alexander; et al.

Bioprinting Volume: 15 Pages: Article No.: e00050 Published: SEP 2019

2. Chitosan nanocomposites for bone and cartilage regeneration

Times Cited: 2

By: Ahmad, Mudasir; Manzoor, Kaiser; Ikram, Saiqa

APPLICATIONS OF NANOCOMPOSITE MATERIALS IN DENTISTRY Book Series: Woodhead Publishing Series in Biomaterials

Pages: 307-317 Published: 2019

3. The application of gene transfer technology in articular cartilage tissue engineering: an insight

Times Cited: 1

By: Ahmad, R; Muhammad, A; Abdulahi, H.

TPGM Volume: 7 Pages: 211-216 Published: 2017

4. Microfabrication of scaffold-free tissue strands for three-dimensional tissue engineering

Times Cited: 42

By: Akkouch, Adil; Yu, Yin; Ozbolat, Ibrahim T.

BIOFABRICATION Volume: 7 Issue: 3 Article Number: 031002 Published: SEP 2015

5. Physical Properties and Biocompatibility of 3D Hybrid PLGA Based Scaffolds

Times Cited: 1

By: Amin, Muhammad Azri Ifwat bin Mohamed; Tahir, Aisyah Hanani Md Ali; Azhim, Azran; et al.

2018 IEEE-EMBS CONFERENCE ON BIOMEDICAL ENGINEERING AND SCIENCES (IECBES) Book Series: IEEE EMBS Conference on Biomedical Engineering and Sciences Pages: 480-484 Published: 2018

6. In-air production of 3D co-culture tumor spheroid hydrogels for expedited drug screening

Times Cited: 11

By: Antunes, Jessica; Gaspar, Vitor M.; Ferreira, Luis; et al.

ACTA BIOMATERIALIA Volume: 94 Pages: 392-409 Published: AUG 2019

7. Volume-by-volume bioprinting of chondrocytes-alginate bioinks in high temperature thermoplastic scaffolds for Times Cited: 8 cartilage regeneration 